\title{
OBSERVING THE DYNAMICS OF THE NAD+ TO NADH RATIO IN DANIO RERIO EMBRYO TISSUES USING A GENETICALLY ENCODED BIOSENSOR
}

\author{
Bilan DS ${ }^{1,2}$, Shokhina AG ${ }^{1}$, Panova $\mathrm{AS}^{1,3}$, Belousov $\mathrm{W}^{1,2} \bowtie$ \\ ${ }^{1}$ Laboratory of Molecular Technologies, \\ Shemyakin-Ovchinnikov Institute of Bioorganic Chemistry, RAS, Moscow, Russia \\ ${ }^{2}$ Department of Brain-Machine Interfaces, Research Institute of Translational Medicine, \\ Pirogov Russian National Research Medical University, Moscow, Russia \\ ${ }^{3}$ Department of Biochemistry, Faculty of Biology, \\ Lomonosov Moscow State University, Moscow, Russia
}

The zebrafish Danio rerio is a popular model species for biomedical research focusing on modeling human diseases and screening of therapeutic drugs. Genetically encoded biosensors based on fluorescent proteins are widely used in many laboratories worldwide to study the biology of living systems of various complexity in vivo. The main advantage of these molecular tools is that they allow observing biological processes in intact systems in real time. In the present work we study the dynamics of the intracellular ratio of $\mathrm{NAD}^{+}$to $\mathrm{NADP}$ in the yolk sac and tissues of $D$. rerio larvae using the SoNar biosensor following the injection of glycolisis end products, lactate and pyruvate.

Keywords: genetically encoded biosensors, Danio rerio, pyruvate, lactate

Funding: this work was supported by the Russian Foundation for Basic Research (Grant 16-34-60175) and the Russian Federation Presidential Grant MK6339.2016.4. Experiments were partially carried out using the equipment provided by the IBCH core facility (CKP IBCH, supported by Russian Ministry of Education and Science, grant RFMEFI62117X0018).

$\triangle$ Correspondence should be addressed: Vsevolod Belousov

ul. Miklukho-Maklaya, d. 16/10, Moscow, Russia, 117997; belousov@ibch.ru

Recieved: 05.12.2017 Accepted: 25.12.2017

DOI: $10.24075 /$ brsmu.2018.005

\section{РЕГИСТРАЦИЯ ДИНАМИКИ СООТНОШЕНИЯ НАДР/НАДН В ТКАНЯХ ЭМБРИОНОВ РЫБ DANIO RERIO С ПОМОЩЬЮ ГЕНЕТИЧЕСКИ КОДИРУЕМОГО БИОСЕНСОРА}

\author{
Д. С. Билан ${ }^{1,2}$, А. Г. Шохина, А. С. Панова 1,3 В. В. Белоусов ${ }^{1,2} \bowtie$ \\ Лаборатория молекулярных технологий, \\ Институт биоорганической химии имени академиков М. М. Шемякина и Ю. А. Овчинникова РАН, Москва \\ ${ }^{2}$ Отдел нейро-компьютерных интерсейсов, НИИ трансляционной медицины, \\ Российский национальный исследовательский медицинский университет имени Н. И. Пирогова, Москва \\ ${ }^{3}$ Кафедра биохимии, биологический факультет, \\ Московский государственный университет имени М.В.Ломоносова, Москва
}

\begin{abstract}
Рыба Danio rerio является популярным модельным объектом во многих медико-биологических исследованиях, в том числе для моделирования человеческих заболеваний и скрининга лекарственных препаратов. Генетически кодируемые биосенсоры на базе флуоресцентных белков широко используются во всем мире для исследований сложных биологических процессов в живых системах любого уровня сложности in vivo. Главное преимущество таких молекулярных инструментов в том, что генетически кодируемые индикаторы позволяют исследователям наблюдать за биологическими процессами в интактных системах в режиме реального времени. В данной работе мы впервые протестировали биосенсор SoNar для регистрации такого важного внутриклеточного параметра, как соотношение НАД+/НАДН, в тканях эмбрионов рыбы D. rerio. Мы исследовали, как изменяется динамика соотношения НАД+/НАДН в желточном мешке и тканях тела малька рыбы при инъекции продуктов гликолиза лактата и пирувата.
\end{abstract}

Ключевые слова: генетически кодируемые биосенсоры, Danio rerio, пируват, лактат

Финансирование: работа выполнена при поддержке гранта Российского фонда фундаментальных исследований мол_а_дк № 16-34-60175 и гранта Президента РФ № МК-6339.2016.4, а также с использованием оборудования ЦКП ИБХ, поддержанного Минобрнауки России, идентификатор соглашения RFMEFI62117X0018.

$\measuredangle$ Для корреспонденции: Белоусов Всеволод Вадимович ул. Миклухо-Маклая, д. 16/10, г. Москва, 117997; belousov@ibch.ru

Статья получена: 05.12.2017 Статья принята к печати: 25.12.2017

DOI: 10.24075/vrgmu.2018.005

The zebrafish Danio rerio is a popular model species for in vivo biomedical research. It has a few advantages over other lab animals: fish are prolific breeders that require little upkeep and develop rapidly. Due to their optical clarity, Danio rerio embryos are a good object for microscopy. Besides, this fish's genome is very well studied and hence easy to manipulate. Therefore, $D$. rerio are often used to study gene functions and developmental biology of vertebrates. Because cell biochemistry and functional activity of proteins in $D$. rerio resemble those of mammals, this species is used for modeling human diseases, testing toxicity of chemical compounds in preclinical trials, and in therapeutic drug screening.

In the last few years $D$. rerio has been successfully exploited as a model organism to study acute lymphoblastic leukemia 
[1-3], melanoma [4, 5], muscular dystrophy [6], diabetes mellitus [7], pathological conditions of the heart [8-10], kidneys $[11,12]$, and central nervous system [13, 14], including brain ischemia $[15,16]$. Such vertebrate models are handy when it comes to investigating effects of various chemical compounds on the organism in health and pathology. The easiest way to administer a compound of interest to the fish is to add it into the water in the tank: the chemical will enter the fish's bloodstream through the gills. The majority of experiments are carried out in larval fish, though, meaning that drugs are normally injected straight into the yolk sac. This method of drug delivery can be employed to assess cardiotoxicity of aspirin, clomipramine, nimodipine, varapamil and some others medications $[17,18]$. Larval fish are also used to study metabolites that are part of normal mammalian biochemistry. For example, in one of the experiments excess amounts of glucose were administered to fish embryos via injections to describe expression profiles of genes involved in carbohydrate metabolism [19]. It is also possible to infect $D$. rerio larvae with injections of bacterial cells to observe how infection progresses [20-22] or even mammalian cells to study tumor growth $[23,24]$

Genetically encoded biosensors based on fluorescent proteins have taken in vivo studies of physiology and pathology to a new level. Each biosensor is a chimeric protein molecule consisting, as a rule, of a sensing moiety and a fluorescent domain. The sensor domain detects changes in the surrounding environment, such as fluctuations in the intracellular concentrations of a studied compound. The fluorescent component "reports" interactions between the sensing domain and the compound of interest, and the obtained signal is then interpreted. Such biosensors are encoded by a gene that can be incorporated into any living organism. What is important is that this approach can be used in real-time imaging of biochemical processes in a living organism [25]. Oftentimes genetically encoded biosensors are the only available tool for looking into complex biological events. Fluorescent biosensors have been extensively used in model $D$. rerio species to study embryogenesis [26], inflammation [27], and organ regeneration [28].

In this work we have pioneered the use of the genetically encoded biosensor SoNar [29] as a tool for monitoring the redox state of nicotinamide adenine dinucleotide (NAD) in the cytoplasm of $D$. rerio tissues. The ratio of its oxidized to reduced forms (NAD+/NADH) is critical not only for cell metabolism but also for the regulation of many signaling cascades [30-32]. We have found out that the $\mathrm{NAD}^{+} / \mathrm{NADH}$ ratio changes both in the yolk sac and body of a $D$. rerio embryo following lactate and pyruvate injections.

The SoNar biosensor [29] is based on the bacterial protein T-Rex of Thermus aquaticus that regulates transcription of a few enzymes in response to fluctuations in the intracellular $\mathrm{NAD}^{+} / \mathrm{NADH}$ ratio. One of the biosensor's components is the fluorescent protein cpYFP integrated into the mobile region of T-Rex. Conformational changes accompanying the binding of T-Rex to $\mathrm{NAD}^{+}$or $\mathrm{NADH}$ are propagated to the fluorescent protein affecting its spectral properties (Fig.1). SoNar fluorescence excitation spectrum typically has two peaks at 420 and $490 \mathrm{~nm}$; the sensor emission peak is at $518 \mathrm{~nm}$. The signal is calculated as a ratio of fluorescence intensities excited at $420 \mathrm{~nm}$ and $490 \mathrm{~nm}\left(\mathrm{~F}_{420} / \mathrm{F}_{490}\right)$ [29]. Thus, the signal is ratiometric, which is particularly important for in vivo research, as it helps to avoid artifacts related to different expression levels of the sensor in different cells, motion, changes of the object's shape or tissue thickness.

\section{METHODS}

$\mathrm{AB} / \mathrm{TL}$ Danio rerio fish were kept in a specially equipped room at $26.5^{\circ} \mathrm{C}$ under $12: 12$ light conditions. The experiments were conducted in compliance with the Declaration of Helsinki. To obtain progeny, parent fish were paired in separate tanks containing $500 \mathrm{ml}$ of E3 medium 4 hours before the lights went out. Eggs were collected when the lights were turned back on.

In our experiment we used SoNar [29] and SypHer-2 [33] biosensors. To obtain larval D.rerio fish expressing these biosensors in their tissues, we synthesized biosensor mRNA in vitro using the commercial mMessage mMachine SP6 Transcription kit (Ambion, USA). Then $1 \mathrm{nl}$ of $0.1 \mu \mathrm{g} / \mu \mathrm{l}$ mRNA was injected into the yolk sac of single-cell fish embryos using Eppendorf Microinjector 5242. The treated fish were kept in Petri dishes at $26.5^{\circ} \mathrm{C}$ under standard $12: 12$ light conditions. Twenty four hours after the injection, the embryos were examined under the fluorescence microscope to select those that were fluorescent. Before microscopy the embryos were manually stripped of chorions, immobilized in $0.02 \%$ tricaine solution and mounted in a drop of $1.5 \%$ low-melting point agarose. One $\mathrm{nl}$ of $200 \mathrm{mM}$ sodium lactate and sodium pyruvate solutions was injected in the yolk sac of each immobilized embryo. Prior to the injections of metabolites, biosensor signals were recorded in the yolk sac and body of each larval fish.

Microscopy was performed using the wide field fluorescence microscope Leica DM6000 (Leica, Germany), equipped with the HC PL FLUOTAR 10.0*0.30 DRY lens. Fluorescence was excited using excitation filters CFP BP436/20 and GFP $\mathrm{BP} 470 / 40$. Frame rate was 1 frame per minute. Images were processed in ImageJ $(\mathrm{NIH})$. Graphs showing the dynamics of sensor signals were constructed using OriginPro 8.6 (OriginLab, USA). The same software was used to process data obtained at each time point.

\section{RESULTS}

We have tested the use of the genetically encoded sensor SoNar [29] in monitoring the $\mathrm{NAD}^{+} / \mathrm{NADH}$ ratio in $D$. rerio tissues. Briefly, we synthesized biosensor mRNA and injected it into the yolk sac of single-cell fish embryos. Twenty four

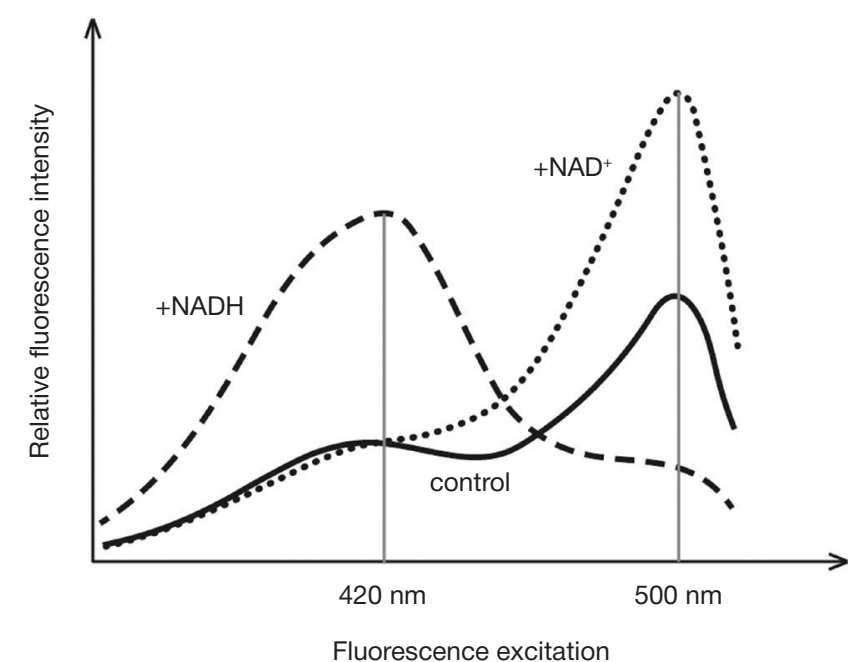

Fig. 1. Fluorescence excitation spectrum of the SoNar protein-based biosensor with two typical peaks at $420 \mathrm{~nm}$ and $490 \mathrm{~nm}$. When $\mathrm{NADH}$ is added, fluorescence intensity increases at $420 \mathrm{~nm}$ and weakens at $490 \mathrm{~nm}$. When NAD+ is added, signal intensity increases at $490 \mathrm{~nm}$. The SoNar biosensor has one emission peak with emission maximum at $518 \mathrm{~nm}$ 
hours after the injection we selected fluorescent embryos for further microscopy. SoNar fluorescence was recorded in two independent channels; fluorescence excitation wavelengths in each channel matched the two peaks of SoNar's fluorescence excitation spectrum (Fig. 1). We obtained two images of each fish embryo at $420 \mathrm{~nm}\left(\mathrm{~F}_{420}\right)$ and $490 \mathrm{~nm}\left(\mathrm{~F}_{490}\right)$ excitation. Using Image we divided the images by one another; the resulting image was then painted in pseudocolors corresponding to the values of the $F_{420} / F_{490}$ ratio (Fig. 2, A, D). Again, using ImageJ we selected a few zones on the embryo's body and made further calculations. Graphs showing the dynamics of the $\mathrm{F}_{420} / \mathrm{F}_{490}$ ratio were constructed in OriginPro 8.6.

To monitor the dynamics of the NAD+/NADH ratio in the embryo tissues of $D$. rerio using the SoNar biosensor, we injected sodium lactate and pyruvate into the embryos. It is well known that the lactate/pyruvate pair is in equilibrium with free cytoplasmic NAD+/NADH owing to the reaction catalyzed by lactate dehydrogenase $[34,35]$. Bearing that in mind, we injected $1 \mathrm{nl}$ of $200 \mathrm{mM}$ sodium lactate solution in the yolk sac of 10 embryos and $1 \mathrm{nl}$ of $200 \mathrm{mM}$ sodium pyruvate solution in the yolk sac of another 11 embryos. Prior to the injections, we recorded the signal emitted by the biosensor in the untreated tissues. This initial value was taken as 1. After the injection, the fish were quickly put under the microscope and imaging was resumed with the same settings. Embryos injected with lactate demonstrated an increase in the $\mathrm{F}_{420} / \mathrm{F}_{490}$ ratio, indicating reduction of the NAD pool (Fig. 2, B). Similar signal dynamics observed in different parts of the embryo's body can be explained by rapid delivery of the metabolites from the yolk sac to other organs. The signal reached its maximum 5 min after the injection, gradually losing its intensity for the next 30 min until it finally reached its initial value, while lactate was being metabolized by cellular organelles. We expected to see an opposite effect with pyruvate. But the $\mathrm{F}_{420} / \mathrm{F}_{490}$ ratio decreased only in the yolk sac and even slightly increased in the embryo's body (Fig. 2, E). It means that small doses of pyruvate trigger different redox events in the intracellular NAD pool: oxidation in the yolk sac and reduction in the embryo's body.

Lactate or pyruvate transport into the cells can happen against the background of changing $\mathrm{pH}$ because it occurs in symport with $\mathrm{H}^{+}[36,37]$. The specific chromophore structure makes fluorescent proteins sensitive to $\mathrm{pH}$ fluctuations [38]. To assess a possible effect of $\mathrm{pH}$ on the SoNar signal intensity, we used SypHer2 previously developed in our lab as a control
(A)

\section{Lactate}

\section{Before the injection}

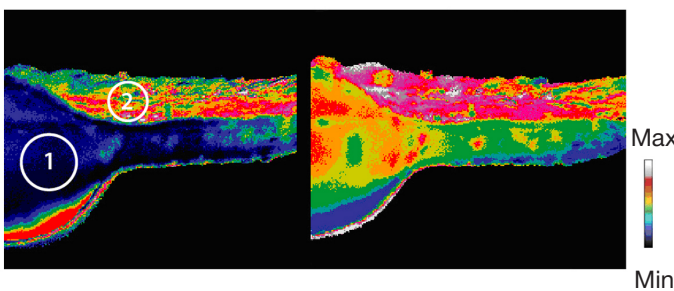

(B)

(C)
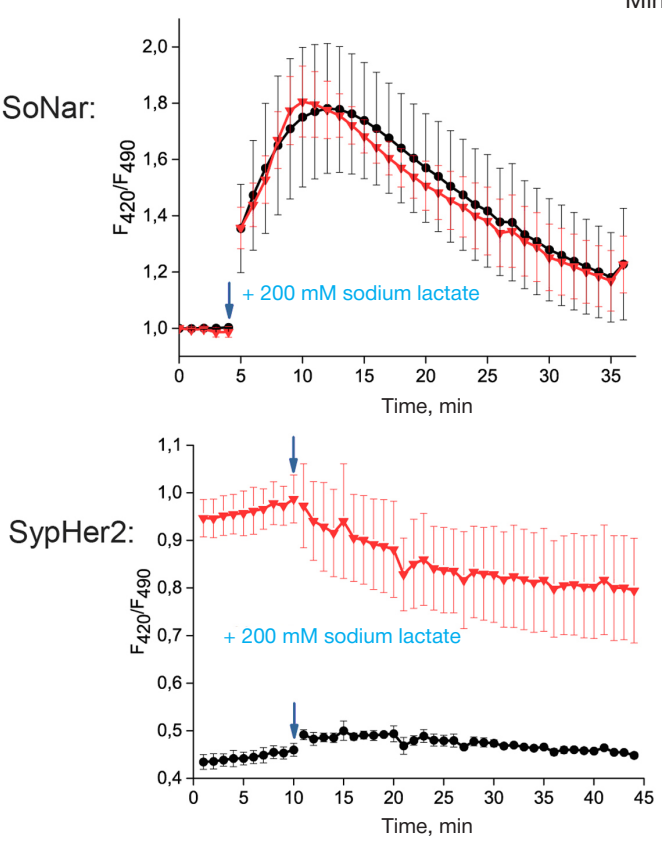

Signal dynamics in
(D)

\section{Pyruvate}

\section{Before the injection SoNar: After the injection of $1 \mathrm{n}$} $200 \mathrm{mM}$ pyruvate solution

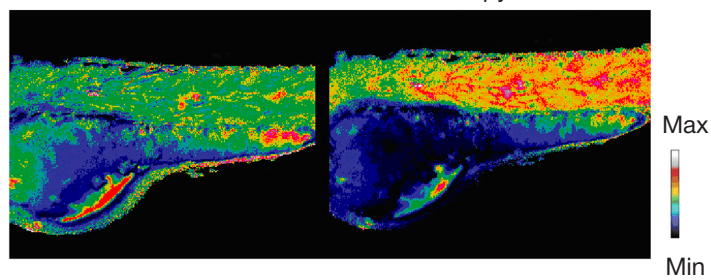

(E)

SoNar:

(F)

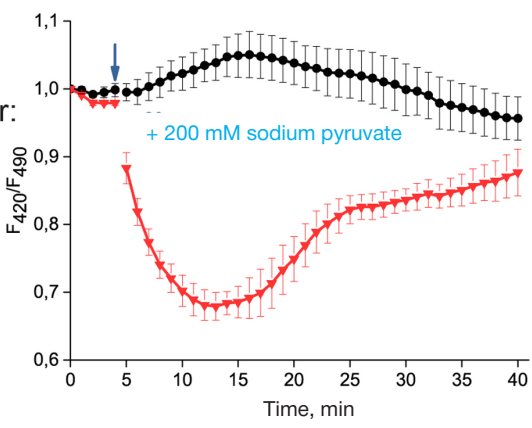

SypHer2:

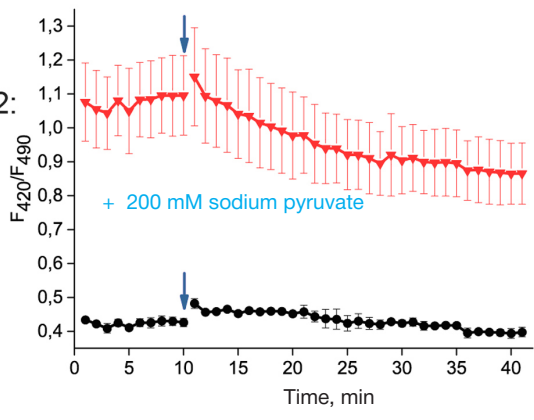

the body of a D.rerio embryo $\smile$ the yolk sac of a D.rerio embryó

Fig. 2. Changes in the NAD+/NADH ratio and $\mathrm{pH}$ in the tissues of one-day old $D$. rerio embryos betore and after pyruvate and lactate injections into the yolk sac. (A and D) Images of a D. rerio embryo body before and after injections of $1 \mathrm{nl} 200 \mathrm{mM}$ lactate (A) and pyruvate (D) solutions. Images are shown in pseudo-colors corresponding to the SoNar signal values $\left(\mathrm{F}_{420} / \mathrm{F}_{400}\right)$. Zones 1 and 2 circled in white in the first picture indicate regions on the embryo's body where $\mathrm{F}_{420} / \mathrm{F}_{490}$ fluctuations were registered. These regions were the same for all inspected fish. (B and E) Changes in the NAD+/NADH ratio measured using the SoNar biosensor in the yolk sac (red line) and body (black line) of the $D$. rerio embryo before and after injections of lactate $(\mathbf{B})$ and pyruvate $(\mathrm{E})$ solutions. (C and $\mathrm{F}) \mathrm{Changes}$ in pH registered using the SypHer2 in the yolk sac (red line) and body (black line) of a D. rerio embryo before and after injections of lactate (C) and pyruvate (F). For all graphs (B, C, E, F) the error bar corresponds to the standard deviation. Graph (C) was constructed based on the imaging of 10 fish. Graph (E) - based on the imaging of 11 fish. Graphs (C) and (F) - based on the imaging of 6 animals (per graph) 
biosensor [33]. We synthesized SypHer2 mRNA and conducted the same series of experiments as with SoNar. Lactate and pyruvate injections did not induce any changes in $\mathrm{pH}$ in the embryos' bodies. Injected into the yolk sac, both metabolites caused a slight and slow increase in $\mathrm{pH}$ in this tissue which lasted for 20 min following the injection (Fig. 2, C, F).

\section{DISCUSSION}

Our findings lead us to conclude that the genetically encoded biosensor SoNar developed to record NAD+/NADH fluctuations can be successfully used in the experiments involving $D$. rerio model species. The $\mathrm{NAD}^{+} / \mathrm{NADH}$ ratio is an important biological parameter that can be significantly affected by pathology. A fish that expresses the SoNar biosensor in its tissues or cells can be effectively used as a model organism to assess the impact of different compounds on the $\mathrm{NAD}^{+} / \mathrm{NADH}$ ratio and therefore on disease progression.

We have found out that lactate injections in the yolk sac cause significant simultaneous reduction of the NAD pool in al tissues of the fish. However, pyruvate injections induce NAD oxidation only in the yolk sac; moreover, they cause slight reduction in the embryo's body. One of the recent works studied the role of redox processes in embryogenesis using the $D$. rerio model to reveal that massive oxidation starts at gastrulation and goes on to subside when the fish is three days old. That work demonstrates that oxidative stress plays a key role in the development of some organs in the course of embryogenesis
[26]. Perhaps, we have not observed significant oxidation in embryo tissues following the pyruvate injection because at this developmental stage redox homeostasis is shifted towards oxidation. Notably, in the article cited above the minimum level of reactive oxygen species (hydrogen peroxide) was observed in the yolk sac - the organ in which (in our experiment) NAD tended to be oxidized after the injection of pyruvate. Insignificant reduction of the NAD pool in the embryo's body is probably compensation.

Another possible explanation is that in the yolk sac pyruvate is reduced to lactate, which can be confirmed by decreased $\mathrm{NADH}$ concentrations, but it is mainly lactate that is transported to the embryo's body. Perhaps, this is why we observed a signal change indicative of a slight elevation of NADH concentrations. This hypothesis needs to be tested.

\section{CONCLUSIONS}

We have demonstrated that the genetically encoded biosensor SoNar developed to measure the $\mathrm{NAD}^{+} / \mathrm{NADH}$ ratio can be used in $D$. rerio tissues. Lactate injections into the yolk sac of a one-day old fish embryo lead to rapid reduction of the NAD pool in all tissues of the fish, showing that substances present in the yolk sac can be easily transported to other tissues. Pyruvate injections induce oxidative reactions in the yolk sac only, accompanied by slight reduction in the embryo's body. Using the control SypHer2, we have established that pyruvate and lactate cause slight $\mathrm{pH}$ fluctuations only in the yolk sac.

\section{References}

1. Langenau DM, Traver D, Ferrando AA, Kutok JL, Aster JC, Kanki JP et al. Myc-induced T cell leukemia in transgenic zebrafish. Science. 2003 Feb 7; 299 (5608): 887-90. DOI: 10.1126/science.1080280.

2. Chen J, Jette C, Kanki JP, Aster JC, Look AT, Griffin JD. NOTCH1induced T-cell leukemia in transgenic zebrafish. Leukemia. 2007 Mar; 21 (3): 462-71. DOI: 10.1038/sj.leu.2404546.

3. Feng H, Stachura DL, White RM, Gutierrez A, Zhang L, Sanda T et al. T-lymphoblastic lymphoma cells express high levels of BCL2, S1P1, and ICAM1, leading to a blockade of tumor cel intravasation. Cancer Cell. 2010 Oct 19; 18 (4): 353-66. DOI: 10.1016/i.ccr.2010.09.009.

4. Patton EE, Widlund HR, Kutok JL, Kopani KR, Amatruda JF, Murphey RD et al. BRAF mutations are sufficient to promote nevi formation and cooperate with p53 in the genesis of melanoma. Curr Biol. 2005 Feb 8; 15 (3): 249-54. DOI: 10.1016/j. cub.2005.01.031.

5. Santoriello C, Gennaro E, Anelli V, Distel M, Kelly A, Koster RW et al. Kita driven expression of oncogenic HRAS leads to early onset and highly penetrant melanoma in zebrafish. PloS One. 2010 Dec 10; 5 (12): e15170. DOI: 10.1371/journal.pone.0015170.

6. Bassett $\mathrm{DI}$, Currie PD. The zebrafish as a model for muscular dystrophy and congenital myopathy. Hum Mol Genet. 2003 Oct 15; 12 Spec No 2: R265-70. DOI: 10.1093/hmg/ddg279.

7. Zang L, Shimada Y, Nishimura N. Development of a nove zebrafish model for type 2 diabetes mellitus. Sci Rep. 2017 May 3; 7 (1): 1461. DOI: 10.1038/s41598-017-01432-w.

8. Stainier DY, Fouquet B, Chen JN, Warren KS, Weinstein BM, Meiler SE et al. Mutations affecting the formation and function of the cardiovascular system in the zebrafish embryo. Development. 1996 Dec; 123: 285-92.

9. Asnani A, Peterson RT. The zebrafish as a tool to identify novel therapies for human cardiovascular disease. Dis Models Mech. 2014 Jul; 7 (7): 763-7. DOI: 10.1242/dmm.016170.

10. Chablais F, Veit J, Rainer G, Jazwinska A. The zebrafish heart regenerates after cryoinjury-induced myocardial infarction. BMC

Dev Biol. 2011 Apr 7: 11: 21. DOl: 10.1186/1471-213X-11-21.

11. Morales EE, Wingert RA. Zebrafish as a model of kidney disease. Results Probl Cell Differ. 2017; 60: 55-75. DOI: 10.1007/978-3319-51436-9_3.

12. Swanhart LM, Cosentino CC, Diep CQ, Davidson AJ, de Caestecker M, Hukriede NA. Zebrafish kidney development: basic science to translational research. Birth Defects Res C Embryo Today. 2011 Jun; 93 (2): 141-56. DOI: 10.1002/bdrc.20209.

13. Martin-Jimenez R, Campanella M, Russell C. New zebrafish models of neurodegeneration. Curr Neurol Neurosci Rep. 2015 Jun; 15 (6): 33. DOI: 10.1007/s11910-015-0555-z.

14. Xi Y, Noble S, Ekker M. Modeling neurodegeneration in zebrafish. Curr Neurol Neurosci Rep. 2011 Jun; 11 (3): 274-82. DOI 10.1007/s11910-011-0182-2.

15. YuX, Li YV. Zebrafish as an alternative model for hypoxic-ischemic brain damage. Int J Physiol Pathophysiol Pharmacol. 2011; 3 (2): 88-96. Epub 2011 Apr 20.

16. Yu X, Li YV. Zebrafish (Danio rerio) developed as an alternative animal model for focal ischemic stroke. Acta Neurochir Suppl. 2016; 121: 115-9. DOI: 10.1007/978-3-319-18497-5_20.

17. Zhu JJ, Xu YQ, He JH, Yu HP, Huang CJ, Gao JM et al. Human cardiotoxic drugs delivered by soaking and microinjection induce cardiovascular toxicity in zebrafish. J Appl Toxicol. 2014; 34 (2): 139-48. DOI: 10.1002/jat.2843.

18. Liang J, Jin $W$, Li H, Liu H, Huang $Y$, Shan $X$, et al. In vivo cardiotoxicity induced by sodium aescinate in zebrafish larvae. Molecules. 2016 Feb 23; 21 (3): 190. DOI: 10.3390/ molecules21030190.

19. Rocha F, Dias J, Engrola S, Gavaia P, Geurden I, Dinis MT et al. Glucose overload in yolk has little effect on the long-term modulation of carbohydrate metabolic genes in zebrafish (Danio rerio). J Exp Biol. 2014 Apr 1; 217 (Pt 7): 1139-49. DOI: 10.1242/ jeb.095463.

20. Cronan MR, Tobin DM. Fit for consumption: zebrafish as a model for tuberculosis. Dis Model Mech. 2014 Jul; 7 (7): 777-84. DOI: 10.1242/dmm.016089. 
21. Mostowy S, Boucontet L, Mazon Moya MJ, Sirianni A, Boudinot $\mathrm{P}$, Hollinshead $\mathrm{M}$ et al. The zebrafish as a new model for the in vivo study of Shigella flexneri interaction with phagocytes and bacterial autophagy. PLoS Pathog. 2013; 9 (9): e1003588. DOI: 10.1371/journal.ppat.1003588.

22. Veneman WJ, Stockhammer OW, de Boer L, Zaat SA, Meijer AH, Spaink HP. A zebrafish high throughput screening system used for Staphylococcus epidermidis infection marker discovery. BMC Genomics. 2013 Apr 15; 14: 255. DOI: 10.1186/1471-2164-14255.

23. Yee NS, Kazi AA, Yee RK. Translating discovery in zebrafish pancreatic development to human pancreatic cancer: biomarkers, targets, pathogenesis, and therapeutics. Zebrafish. 2013 Jun; 10 (2): 132-46. DOI: 10.1089/zeb.2012.0817.

24. Lee HJ, Yang YJ, Jeong S, Lee JD, Choi SY, Jung DW et al. Development of a vestibular schwannoma xenograft zebrafish model for in vivo antitumor drug screening. Laryngoscope. 2016 Dec; 126 (12): E409-E415. DOI: 10.1002/lary.26043.

25. Bilan DS, Belousov V. New tools for redox biology: From imaging to manipulation. Free Radic Biol Med. 2017 Aug; 109: 167-88. DOI: 10.1016/freeradbiomed.2016.12.004.

26. Gauron C, Meda F, Dupont E, Albadri S, Quenech'Du N, Ipendey $\mathrm{E}$ et al. Hydrogen peroxide $\left(\mathrm{H}_{2} \mathrm{O} 2\right)$ controls axon pathfinding during zebrafish development. Dev Biol. 2016 Jun 15; 414 (2): 133-41. DOI: 10.1016/j.ydbio.2016.05.004.

27. Niethammer P, Grabher C, Look AT, Mitchison TJ. A tissue-scale gradient of hydrogen peroxide mediates rapid wound detection in zebrafish. Nature. 2009 Jun 18; 459 (7249): 996-9. DOI: 10.1038/nature08119.

28. Han $\mathrm{P}$, Zhou XH, Chang $\mathrm{N}$, Xiao CL, Yan S, Ren $\mathrm{H}$ et al. Hydrogen peroxide primes heart regeneration with a derepression mechanism. Cell Res. 2014 Sep; 24 (9): 1091-107. DOI: 10.1038/ cr.2014.108.

29. Zhao Y, Hu Q, Cheng F, Su N, Wang A, Zou Y et al. SoNar, a highly responsive NAD+/NADH sensor, allows high-throughput metabolic screening of anti-tumor agents. Cell metab. 2015 May;

\section{Литература}

1. Langenau DM, Traver D, Ferrando AA, Kutok JL, Aster JC, Kanki JP et al. Myc-induced T cell leukemia in transgenic zebrafish. Science. 2003 Feb 7; 299 (5608): 887-90. DOI: 10.1126/science.1080280.

2. Chen J, Jette C, Kanki JP, Aster JC, Look AT, Griffin JD. NOTCH1induced T-cell leukemia in transgenic zebrafish. Leukemia. 2007 Mar; 21 (3): 462-71. DOI: 10.1038/sj.leu.2404546.

3. Feng H, Stachura DL, White RM, Gutierrez A, Zhang L, Sanda T et al. T-lymphoblastic lymphoma cells express high levels of BCL2, S1P1, and ICAM1, leading to a blockade of tumor cell intravasation. Cancer Cell. 2010 Oct 19; 18 (4): 353-66. DOI: 10.1016/j.ccr.2010.09.009.

4. Patton EE, Widlund HR, Kutok JL, Kopani KR, Amatruda JF, Murphey RD et al. BRAF mutations are sufficient to promote nevi formation and cooperate with p53 in the genesis of melanoma. Curr Biol. 2005 Feb 8; 15 (3): 249-54. DOI: 10.1016/j. cub.2005.01.031.

5. Santoriello C, Gennaro E, Anelli V, Distel M, Kelly A, Koster RW et al. Kita driven expression of oncogenic HRAS leads to early onset and highly penetrant melanoma in zebrafish. PloS One. $2010 \mathrm{Dec}$ 10; 5 (12): e15170. DOI: 10.1371/journal.pone.0015170.

6. Bassett DI, Currie PD. The zebrafish as a model for muscular dystrophy and congenital myopathy. Hum Mol Genet. 2003 Oct 15; 12 Spec No 2: R265-70. DOI: 10.1093/hmg/ddg279.

7. Zang L, Shimada Y, Nishimura N. Development of a novel zebrafish model for type 2 diabetes mellitus. Sci Rep. 2017 May 3; 7 (1): 1461. DOI: 10.1038/s41598-017-01432-W.

8. Stainier DY, Fouquet B, Chen JN, Warren KS, Weinstein BM, Meiler SE et al. Mutations affecting the formation and function of the cardiovascular system in the zebrafish embryo. Development. 1996 Dec; 123: 285-92.

9. Asnani A, Peterson RT. The zebrafish as a tool to identify novel
21 (5): 777-89. DOI: 10.1016/j.cmet.2015.04.009

30. Ying W. NAD+ and NADH in cellular functions and cell death. Front Biosci. 2006 Sep 1; 11: 3129-48.

31. Ying $W$. NAD+/NADH and NADP+/NADPH in cellular functions and cell death: regulation and biological consequences. Antioxid Redox Signal. 2008 Feb; 10 (2): 179-206. DOl: 10.1089/ ars.2007.1672.

32. Verdin $\mathrm{E} . \mathrm{NAD}(+)$ in aging, metabolism, and neurodegeneration. Science. 2015 Dec 4; 350 (6265): 1208-13. DOI: 10.1126/ science.aac4854.

33. Matlashov ME, Bogdanova YA, Ermakova GV, Mishina NM, Ermakova YG, Nikitin ES et al. Fluorescent ratiometric $\mathrm{pH}$ indicator SypHer2: Applications in neuroscience and regenerative biology. Biochim Biophys Acta. 2015 Nov; 1850 (11): 2318-28. DOI: 10.1016/j.bbagen.2015.08.002.

34. Bucher T, Brauser B, Conze A, Klein F, Langguth O, Sies H. State of oxidation-reduction and state of binding in the cytosolic NADHsystem as disclosed by equilibration with extracellular lactatepyruvate in hemoglobin-free perfused rat liver. Eur J Biochem. 1972 May 23; 27 (2): 301-17.

35. Williamson $\mathrm{DH}$, Lund $\mathrm{P}$, Krebs HA. The redox state of free nicotinamide-adenine dinucleotide in the cytoplasm and mitochondria of rat liver. Biochem J. 1967 May; 103 (2): 514-27.

36. Poole RC, Halestrap AP. Transport of lactate and other monocarboxylates across mammalian plasma membranes. Am J Physiol. 1993 Apr; 264 (4 Pt 1): C761-82. DOI: 10.1152/ ajpcell.1993.264.4.C761.

37. Zima AV, Kockskamper J, Mejia-Alvarez R, Blatter LA. Pyruvate modulates cardiac sarcoplasmic reticulum $\mathrm{Ca} 2+$ release in rats via mitochondria-dependent and -independent mechanisms. J Physiol. 2003; 550 (Pt 3): 765-83.

38. Elsliger MA, Wachter RM, Hanson GT, Kallio K, Remington SJ. Structural and spectral response of green fluorescent protein variants to changes in $\mathrm{pH}$. Biochemistry. $1999 \mathrm{Apr} 27$; 38 (17): 5296-301. DOI: 10.1021/bi9902182. therapies for human cardiovascular disease. Dis Models Mech. 2014 Jul; 7 (7): 763-7. DOI: 10.1242/dmm.016170.

10. Chablais $F$, Veit J, Rainer $G$, Jazwinska A. The zebrafish heart regenerates after cryoinjury-induced myocardial infarction. BMC Dev Biol. 2011 Apr 7; 11: 21. DOI: 10.1186/1471-213X-11-21.

11. Morales EE, Wingert RA. Zebrafish as a model of kidney disease. Results Probl Cell Differ. 2017; 60: 55-75. DOI: 10.1007/978-3319-51436-9_3.

12. Swanhart LM, Cosentino CC, Diep CQ, Davidson AJ, de Caestecker M, Hukriede NA. Zebrafish kidney development: basic science to translational research. Birth Defects Res C Embryo Today. 2011 Jun; 93 (2): 141-56. DOI: 10.1002/bdrc.20209.

13. Martin-Jimenez R, Campanella M, Russell C. New zebrafish models of neurodegeneration. Curr Neurol Neurosci Rep. 2015 Jun; 15 (6): 33. DOI: 10.1007/s11910-015-0555-z.

14. $\mathrm{Xi} Y$, Noble S, Ekker M. Modeling neurodegeneration in zebrafish. Curr Neurol Neurosci Rep. 2011 Jun; 11 (3): 274-82. DOl: 10.1007/s11910-011-0182-2.

15. YuX, Li YV. Zebrafish as an alternative model for hypoxic-ischemic brain damage. Int J Physiol Pathophysiol Pharmacol. 2011; 3 (2): 88-96. Epub 2011 Apr 20.

16. Yu X, Li YV. Zebrafish (Danio rerio) developed as an alternative animal model for focal ischemic stroke. Acta Neurochir Suppl. 2016; 121: 115-9. DOI: 10.1007/978-3-319-18497-5_20.

17. Zhu JJ, Xu YQ, He JH, Yu HP, Huang CJ, Gao JM et al. Human cardiotoxic drugs delivered by soaking and microinjection induce cardiovascular toxicity in zebrafish. J Appl Toxicol. 2014; 34 (2): 139-48. DOI: 10.1002/jat.2843.

18. Liang J, Jin W, Li H, Liu H, Huang $Y$, Shan $X$, et al. In vivo cardiotoxicity induced by sodium aescinate in zebrafish larvae. Molecules. 2016 Feb 23; 21 (3): 190. DOI: 10.3390/ molecules21030190. 
19. Rocha F, Dias J, Engrola S, Gavaia P, Geurden I, Dinis MT et al. Glucose overload in yolk has little effect on the long-term modulation of carbohydrate metabolic genes in zebrafish (Danio rerio). J Exp Biol. 2014 Apr 1; 217 (Pt 7): 1139-49. DOl: 10.1242/ jeb.095463.

20. Cronan MR, Tobin DM. Fit for consumption: zebrafish as a model for tuberculosis. Dis Model Mech. 2014 Jul; 7 (7): 777-84. DOI: $10.1242 / \mathrm{dmm} .016089$.

21. Mostowy S, Boucontet L, Mazon Moya MJ, Sirianni A, Boudinot $\mathrm{P}$, Hollinshead $\mathrm{M}$ et al. The zebrafish as a new model for the in vivo study of Shigella flexneri interaction with phagocytes and bacterial autophagy. PLoS Pathog. 2013; 9 (9): e1003588. DOI: 10.1371/journal.ppat.1003588.

22. Veneman WJ, Stockhammer OW, de Boer L, Zaat SA, Meijer AH, Spaink HP. A zebrafish high throughput screening system used for Staphylococcus epidermidis infection marker discovery. BMC Genomics. 2013 Apr 15; 14: 255. DOI: 10.1186/1471-2164-14255.

23. Yee NS, Kazi AA, Yee RK. Translating discovery in zebrafish pancreatic development to human pancreatic cancer: biomarkers, targets, pathogenesis, and therapeutics. Zebrafish. 2013 Jun; 10 (2): 132-46. DOI: 10.1089/zeb.2012.0817.

24. Lee HJ, Yang YJ, Jeong S, Lee JD, Choi SY, Jung DW et al Development of a vestibular schwannoma xenograft zebrafish model for in vivo antitumor drug screening. Laryngoscope. 2016 Dec; 126 (12): E409-E415. DOI: 10.1002/lary.26043.

25. Bilan DS, Belousov W. New tools for redox biology: From imaging to manipulation. Free Radic Biol Med. 2017 Aug; 109: 167-88. DOI: 10.1016/freeradbiomed.2016.12.004.

26. Gauron C, Meda F, Dupont E, Albadri S, Quenech'Du N, Ipendey $\mathrm{E}$ et al. Hydrogen peroxide $\left(\mathrm{H}_{2} \mathrm{O} 2\right)$ controls axon pathfinding during zebrafish development. Dev Biol. 2016 Jun 15; 414 (2): 133-41. DOI: 10.1016/j.ydbio.2016.05.004.

27. Niethammer P, Grabher C, Look AT, Mitchison TJ. A tissue-scale gradient of hydrogen peroxide mediates rapid wound detection in zebrafish. Nature. 2009 Jun 18; 459 (7249): 996-9. DOl: 10.1038/nature08119.

28. Han $\mathrm{P}$, Zhou XH, Chang $\mathrm{N}$, Xiao $\mathrm{CL}$, Yan $\mathrm{S}$, Ren $\mathrm{H}$ et al Hydrogen peroxide primes heart regeneration with a derepression mechanism. Cell Res. 2014 Sep; 24 (9): 1091-107. DOI: 10.1038/ cr.2014.108.
29. Zhao $Y, H u$ Q, Cheng F, Su N, Wang A, Zou $Y$ et al. SoNar, a highly responsive NAD+/NADH sensor, allows high-throughput metabolic screening of anti-tumor agents. Cell metab. 2015 May; 21 (5): 777-89. DOI: 10.1016/j.cmet.2015.04.009.

30. Ying W. NAD+ and NADH in cellular functions and cell death. Front Biosci. 2006 Sep 1; 11: 3129-48.

31. Ying $W$. NAD+/NADH and NADP+/NADPH in cellular functions and cell death: regulation and biological consequences. Antioxid Redox Signal. 2008 Feb; 10 (2): 179-206. DOl: 10.1089/ ars.2007.1672.

32. Verdin $\mathrm{E} . \mathrm{NAD}(+)$ in aging, metabolism, and neurodegeneration. Science. 2015 Dec 4; 350 (6265): 1208-13. DOI: 10.1126/ science.aac4854.

33. Matlashov ME, Bogdanova YA, Ermakova GV, Mishina NM, Ermakova YG, Nikitin ES et al. Fluorescent ratiometric $\mathrm{pH}$ indicator SypHer2: Applications in neuroscience and regenerative biology. Biochim Biophys Acta. 2015 Nov; 1850 (11): 2318-28. DOI: 10.1016/j.bbagen.2015.08.002.

34. Bucher T, Brauser B, Conze A, Klein F, Langguth O, Sies H. State of oxidation-reduction and state of binding in the cytosolic NADHsystem as disclosed by equilibration with extracellular lactatepyruvate in hemoglobin-free perfused rat liver. Eur $\mathrm{J}$ Biochem. 1972 May 23; 27 (2): 301-17.

35. Williamson $\mathrm{DH}$, Lund $\mathrm{P}$, Krebs $\mathrm{HA}$. The redox state of free nicotinamide-adenine dinucleotide in the cytoplasm and mitochondria of rat liver. Biochem J. 1967 May; 103 (2): 514-27.

36. Poole RC, Halestrap AP. Transport of lactate and other monocarboxylates across mammalian plasma membranes. Am J Physiol. 1993 Apr; 264 (4 Pt 1): C761-82. DOI: 10.1152/ ajpcell.1993.264.4.C761.

37. Zima AV, Kockskamper J, Mejia-Alvarez R, Blatter LA. Pyruvate modulates cardiac sarcoplasmic reticulum $\mathrm{Ca} 2+$ release in rats via mitochondria-dependent and -independent mechanisms. J Physiol. 2003; 550 (Pt 3): 765-83.

38. Elsliger MA, Wachter RM, Hanson GT, Kallio K, Remington SJ. Structural and spectral response of green fluorescent protein variants to changes in $\mathrm{pH}$. Biochemistry. $1999 \mathrm{Apr} 27 ; 38$ (17): 5296-301. DOI: 10.1021/bi9902182. 